\title{
Editorial
}

\section{Tax avoidance and tax competition}

\author{
Barry Bracewell-Milnes, Banstead, United Kingdom
}

'People of the same trade seldom meet together, even for merriment and diversion, but the conversation ends in a conspiracy against the public, or in some contrivance to raise prices.' (Adam Smith, The Wealth of Nations) Similarly, taxgatherers seldom meet their colleagues from other countries, even on social occasions, without seeking to intensify the co-operation between national tax authorities in the struggle against international tax avoidance (reduction).

An unfair comparison? Are not the tax authorities seeking to implement the will of their national Parliaments, whereas merchants and traders are merely seeking to advance their private interests? The answer is that the Public Choice school of economic analysis has taught us to assess the motives and actions of public officials by the same criteria as we apply to those of private persons: both pursue private interests which may or may not overlap (or, at the extreme, coincide with) the public good.

What tames merchants and traders and obliges them, even reluctantly, to serve the common interest in serving their own is the force of competition at home and abroad. Where competition is weak or absent, the trader becomes in greater or lesser degree a monopolist and the economic theory of monopoly has identified and measured the divergences between the common interest and the interest of a monopolist. Both domestically and internationally, traders may seek monopoly profits through the establishment of a cartel; and domestic interest may seek protection from the competition of international free trade.

All this is directly relevant to the relations of tax authorities with other tax authorities and with taxpayers. Tax authorities are an extreme form of government trading monopoly, operating in the commercial market from a position privileged by legislation. These privileges can be weakened by competition or strengthened through international co-operation in policing tax avoidance (reduction) and co-ordinating rates of tax.

Rates of tax can be co-ordinated or harmonised in two quite different ways - averaging and competition. Averaging is the method traditionally favoured by the European Commission. It reduces or precludes international competition and tends to increase rates of tax by introducing or increasing tax minima (because high rates of tax are a problem only for the State imposing them, whereas low rates of tax may constitute a threat to all the other States concerned, which may consequently seek the Commission's protection from this international competition). Harmonisation through international competition, on the other hand, has the same consequences as international competition in goods and services: just as international free trade exerts a downward pressure on the prices of goods and services, so harmonisation of tax rates through competition exerts a downward pressure on tax rates, since business will tend to move from higher-tax to lower-tax regimes. Harmonisation through competition is the method used to achieve compatibility between States taxes and between local taxes in a number of Federations, including Switzerland and the United States. Within the European Community its most notable supporter was the former British Chancellor of the Exchequer Nigel Lawson (who did not, however, extend his own principle to the British excise duties on alcohol and tobacco, which are among the highest in the Community). But the European Commission and most member governments are sceptical or hostile to tax competition.

Why is this? If the wealth of nations is increased by international free trade and reduced by protection and international cartels, can the opposite be true for tax systems? Is it really in the public interest for tax systems to be harmonised through standardisation and the suppression of differences and particularities that enable the taxpayer to play off one tax system against another?

The real reason why governments which favour competition and free trade in commercial contexts nevertheless support tax cartels and other forms of co-operation between national tax authorities is that governments and tax authorities are unwilling to accept the devolution of power from themselves to the taxpayers that tax competition would bring. This attitude is rationalised by two main arguments, first, that tax avoidance and reduction inflict losses on 
other taxpayers and, second, that they inflict losses on the fisc itself. Neither argument is true as a general proposition (although both may be true on occasion). Money accruing to the fisc through tax co-ordination and enforcement may be used to finance additional government expenditure rather than the reduction of other taxes; and effective tax enforcement may reduce rather than increase the yield of the tax system if its main effect is to reduce the level of economic activity or to distort its pattern.

International tax co-operation and standardisation are themselves in competition with international tax competition as means of achieving the international tax regime that inflicts the least damage on the process of wealth creation. They are in conflict with the ethos of international free trade and they impose what may be heavy or even punitive costs on particular forms of economic activity. There is thus a presumption in favour of competitive solutions to problems of international tax policy, however uncongenial such solutions may be to the instincts of taxgatherers.

Good news for those involved in financial services ...

\section{AMSTERDAM FINANCIAL SERIES}

\section{Comprehensive guide}

Amsterdam Financial Series provides both practitioners and academics with a comprehensive guide to the impact of European Community regulation on financial services, such as Banking, Insurance, Investment, Accountancy, Legal and Financial Consultancy and Stock Exchange.

\section{Expertise}

This unique new series has been produced under authority of general editor Martijn van Empel with the assistance of a number of experts who have been personally involved in the gestation of this intricate but fascinating field of law. It has been published under the responsibility of the Europa Institute of the University of Amsterdam, and under the aegis of "Amsterdam Financial Centre".

\section{Practical set-up}

Amsterdam Financial Series is divided into four parts. The first volumes regroup all materials and cases which are relevant to the subject. Other volumes will consist of commentaries on the various subjects. New develop-ments can be incorporated on a regular basis by means of future supplements.

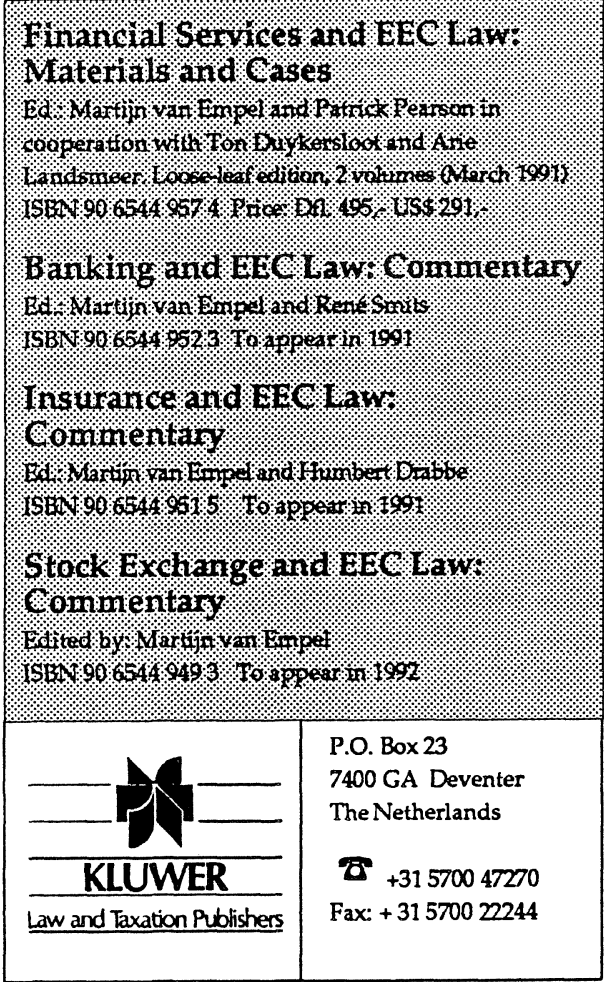

Finaricial Services and EEC I. WW:



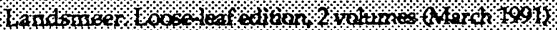

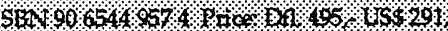

Banking andEEOLaw. Comnentary

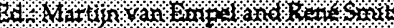
Commentary

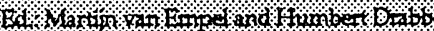

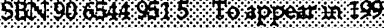

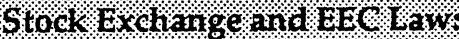
Qomnentang

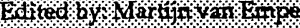

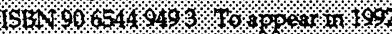

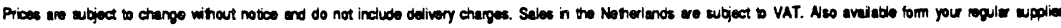

